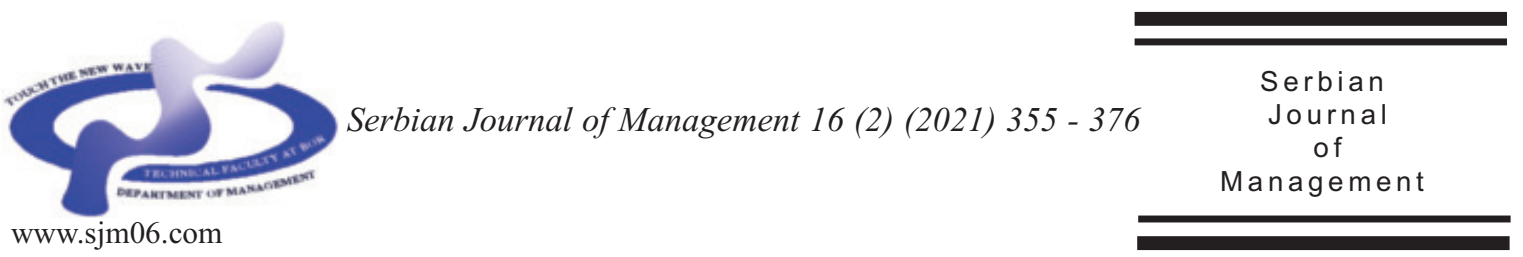

\title{
IMPACT OF PREMIUM RESERVE ON LIFE INSURANCE INVESTMENTS IN THE WESTERN BALKANS
}

\author{
Jelena Tomašević, Milijana Novović Burić*, Ljiljana Kašćelan and \\ Vladimir Kašćelan \\ University of Montenegro, Faculty of Economics, 37 Bulevar Jovana Tomaševića, \\ 81000 Podgorica, Montenegro
}

(Received 18 August 2020; accepted 02 March 2021)

\begin{abstract}
The growing importance of life insurance in the world imposes a greater need for research in this area, particularly in the Western Balkans where the trend of growth has been closely accompanied by life insurance for the past two decades. Taking into consideration that life insurance companies are significant participants in the financial market, this research paper examines the impact of the premium reserve on the volume of financial investments of life insurance companies in Western Balkan countries, based on aggregate data on country level. In order to test its effect, linear correlation and regression models were used, based on data collected for the period 2006-2016. Additionally, comparative analysis was used to compare the position of life insurance companies in financial markets. The results obtained by applying correlation and regression analysis showed that there is a strong positive correlation between premium reserve and financial investments in all of the aforementioned countries in the region. This result is an important strategic guideline for the regulators and policymakers to make advancements in the life insurance sector as well as in the financial market of the Western Balkans.
\end{abstract}

Key words: premium reserve, financial investments, life insurance, regression, correlation

\section{INTRODUCTION}

Insurance companies are not only important for protecting the lives and properties of citizens, but they also emerge as important participants in the financial market due to the investments of free funds raised through premiums. A stable and constant flow of insurance premiums, longterm source of funds, long-term investments, time discrepancies between payment of insurance premium and sum insured, the predictability of the occurrence of an insured event are all characteristics that make life

\footnotetext{
*Corresponding author:mnovovic@ucg.ac.me
}

DOI: $10.5937 /$ sjm16-28022 
insurance companies significant participants in the financial market (Labudović, 2007). As much as the company wants to make a return on its investment, the safety of the insured, who has made the risk transfer to the insurer, must be primarily taken into account. For this reason, companies invest most of their free funds in low-risk forms of assets such as government bonds and bank deposits (Kočović et al., 2015).

Due to the various specific characteristics of Western Balkan countries, life insurance markets are significantly underdeveloped in the region. The dominant factors affecting the development of life insurance in the region are certainly the low standard of living, the long transition period, the mistrust of residents in financial institutions, the concentration of a large number of insurers in a relatively small and underdeveloped market, the unregulated financial market, the difficulty to control the investment of the technical reserves of most insurers as a consequence of the accumulated problems caused by inadequate investment policies in the past, underdeveloped legislation and regulatory institutions (Kozarević \& Šiljegović, 2011). However, despite all these limitations, life insurance companies are significant institutional investors in the financial market.

The importance of strengthening the position of the insurance sector in the financial market is highlighted by numerous authors (Labudović, 2007; Piljan et al., 2015; Webb et al., 2002; Arena, 2008). In developing countries, and especially in the Western Balkans, it is very important to develop strategies for strengthening their role as institutional investors, because the life insurance market is in the development phase while banks are mostly dominant in the financial market (Müller-Jentsch, 2007).
There are a number of studies that explore the degree of development of life insurance in Western Balkans countries (Kašćelan \& Radulović, 2008; Kozarević et al., 2011; Kjosevski, 2012; Novović Burić et al., 2017; Bejtja, 2018). However, there has been a lack of research on the potential of this sector to strengthen the position of insurance companies in the financial market for the Western Balkans region, which was the key motive for this paper. Labudović (2008) emphasizes the importance of the type of a life insurance contract, i.e. premium reserve, for financial investment opportunities and points that this indicator may be relevant for evaluating the mentioned potential.

Accordingly, this paper aims to examine the impact of the premium reserve on the volume of financial investments of life insurance companies in Western Balkan countries. The study is focused on this impact because the premium reserve and the structure of financial investments are very important indicators of the life insurance market development and the potential for strengthening the position of this sector in the financial market, and, as already pointed out, there were causal links between these variables which thus far had been poorly studied. For this reason, this paper explores a research question that analyzes the impact of changes in the volume of premium reserve on the volume of financial investments in Western Balkan countries.

Due to the lack of studies on this topic in the Western Balkans, quantifying the impact of the premium reserve on the volume of financial investments, the research result can be important for insurance companies, analysts, policymakers and at the same time can serve as a stimulus for further exploration of the impact of life insurance on the financial market. 
In order to answer the question raised by this research, a correlation and regression model use data on premium reserve and financial investments, collected for the following countries of the region: Montenegro, Croatia, Serbia, Macedonia and Albania, in the period 2006-2016. The data of premium reserves and financial investments were collected from official reports, published by several insurance supervisory agencies in the observed countries: Insurance Supervision Agency Montenegro - ANO, Croatian Financial Services Supervisory Agency - HANFA, National Bank of Serbia - NBS, The Insurance Supervision Agency of the Republic of Macedonia, Albanian financial supervisory authority. The data for Bosnia and Herzegovina are not available as a whole, but only for companies that deal in the territory of Republika Srpska, and therefore Bosnia and Herzegovina is excluded from the analysis.

The paper is structured in three sections. The first part of the paper is an introduction, followed by a brief review of the literature. The second chapter deals with the specifics of the insurance market in the countries of the region and the position of life insurance companies in the financial market, namely the chapter is about data and research methodology. The answers of research questions, obtained using the correlation and regression model are described in the third chapter of the paper. This is followed by the conclusion and references.

\section{LITERATURE REVIEW}

Due to the fact that life insurance in Western Balkans countries began to significantly develop only after 2000, most of the researches on life insurance of the region has been conducted in the last two decades.

Kašćelan and Radulović (2008) studied the level of development of the insurance market in the region. They concluded that, with the exception of Slovenia and Croatia, this market was significantly behind the developed European countries. The fact that the insurance market in Montenegro is underdeveloped was also determined by Novović Burić et al. (2017). The results obtained in this paper showed that the life insurance market had notably progressed over the period observed by Kašćelan and Radulović (2008). In recent years, Montenegro has been in a better position than most countries in the region when it comes to the level of life insurance development and the position of insurers in the financial market. However, certain reforms of the insurance market in the countries of the region still need to be implemented. The development of life insurance and other segments of the insurance market should contribute to improving the position of insurance companies in financial markets and to positively influence the development of the entire region (Novović Burić et al., 2017).

Kozarević et al. (2011) showed that the level of insurance sector development in the countries of the region depended remarkably on the degree of the European integration achieved. They also concluded that the most developed insurance sector was in Croatia and that all other countries in the region were significantly lagging behind. This shows that the opportunities for developing life insurance in the region are underutilized and that real opportunities for a significant progress exist in this area. As Western Balkan countries move closer to the EU and 
the more the legal framework of these countries aligns with EU directives, the life insurance sector is developing faster. It is realistic to expect that this sector will reach a higher level of development as all countries of the region move closer to the status of EU member states.

The main indicators of the life insurance sector's development are insurance density and penetration. Kjosevski (2012) concluded that these indicators were growing in line with per capita income growth. Accordingly, it was concluded that it was necessary to work on increasing personal income in the countries of the region to improve life insurance. Kjosevski points out that Western Balkan countries represent a region with great potential for the dynamic and successful growth of the life insurance sector. On the other hand, Kukaj et al. (2019) show that life insurance has also great importance for economic growth in developing countries such as the Western Balkan countries.

Insurance companies have great importance in the financial market. As Labudović (2007) points out, that life insurance companies have similar functions as the financial market, such are the savings, liquidity, credit function, risk protection, macroeconomic function, etc. The author also emphasizes the much greater importance of life insurance companies than non-life insurance companies in the financial market, due to the differences in the maturity of insurance companies' liabilities. In other words, the development of life insurance, as well as the one of financial market, is in a strong relation. The development of one of these markets encourages the development of the other one, and the lack of development and progress on one causes the decline and problems in the other market.
The fact that insurance companies significantly drive the development of the financial market is emphasized by Piljan et al. (2015). The authors emphasize that the growth of the capital market is driven by insurance development, primarily because insurance generates a large amount of capital that has a positive impact on financial flows and the financial market. Dervishi (2020) noticed that insurance companies contributed to the accumulation of financial resources on the financial market through the placement of technical reserves, especially premium reserves. He emphasizes that approximately 95 percent of the existing financial assets of Macedonian insurance companies consist of government bonds and bank deposits.

The position of insurance companies in the financial market dominantly determines the volume of financial investments. Based on life insurance contracts, the company allocates a premium reserve. The reserve's free funds are then invested in various forms of short-term and long-term assets in the financial market, all to generate a certain return so that insurers can meet their obligations under the insurance contracts. It follows that the type of life insurance contract affects the amount of premium collected, which further means that the type of contract also affects the amount of premium reserve and the volume of investments (Labudović, 2008). Therefore, it is obvious that life insurance companies, through the mobilization of funds from the insured, investing a portion of their funds in the financial market and link economic entities: those with surplus and those with a deficit, which explains the way they support significant investment projects and enhance the efficiency of the financial market.

According to Müller-Jentsch (2007), the main features of the financial market in the 
Western Balkans are: the turbulence and the instability during the 1990s, the modernization of the legal framework, the privatization of the banks, a foreign investment growth, an expansion of the range of available financial instruments, the beginning of the insurance sector development. Certain reforms need to be implemented to encourage further development of the financial market in the region. The best situation concerning the level of development of the life insurance and financial markets is in Croatia, while in all other countries the banking sector is still much more developed than the insurance sector.

Most authors believe that the development of the insurance sector can significantly stimulate the economic growth of a country and that it should be considered as an inevitable part of stable economic development (Peleckienė et al., 2019; Webb et al., 2002; Arena, 2008; Kjosevski, 2012). For example, Pradhan et al. (2020) examined the interaction among banking competition, stock and insurance market development, and economic growth of European countries over 1996-2016, using a panel vector errorcorrection model for the empirical investigation. They found causality from banking competition, insurance market development, and stock market development to economic growth and showed that insurance market as an important segment of the financial market enhanced sustainable economic growth in EU. Apergis and Poufinas (2020) confirmed the findings of the existing literature that gross premia and insurance penetration are also significantly and positively related to economic growth. On the other hand, Omarkhanova (2019) showed that first of all, the insurance market depended on global economic development trends and on the productivity of bank lending to individuals in the state. Ward and Zurbruegg (2000) show in their paper that the development of the insurance sector does not necessarily mean economic growth, but that in some countries the effect may also be counterproductive. The relationship between these variables differs from country to country and is significantly conditioned by national circumstances. Similar results were also obtained by Sawadogo et al. (2018). An analysis of the data for 86 developing countries showed that the development of life insurance had a positive impact on economic growth, but also this influence varied depending on the structural characteristics of the countries.

Summarizing previous research, it can be concluded that the life insurance sector plays an important role in the financial market. The development of this sector is a prerequisite for stable economic development. In the Western Balkans, the financial market is dominated by banks, so it is important to strengthen the position of insurance companies by encouraging financial investments. In order to develop adequate strategies to strengthen the role of the life insurance sector in the financial market, it is necessary to initially examine how much the premium reserve affects the volume of financial investments.

A review of the existing papers shows that authors mainly analyzed the level of insurance development and the life insurance market in Western Balkan countries. There is no study examining how much life insurance companies contribute to the development of the financial market, by analyzing the impact of the premium reserve on the volume and structure of financial investments. Some previous research highlights the financial function of insurance companies as 
institutional investors, but does not explore the conditions that strengthen their position in the financial market. In order to overcome the perceived gap and improve the current research on this topic, this paper analyzes the impact of the premium reserve of life insurance companies on the volume of financial investments in Western Balkan countries. This creates a key foundation for strengthening the position of these companies in the financial market of the observed countries.

\section{LIFE INSURANCE MARKET IN THE WESTERN BALKANS}

The following tables provide an overview of some of the indicators of the life insurance market development in the observed countries. All indicators for each observed country are the data at the aggregate level.

Table 1 shows the total life insurance premium as a significant indicator of the life insurance market development.

Table 1 shows that the total life insurance premium is the highest in Croatia and the lowest in Albania. Considering the living standard and economic conditions in Croatia, as well as the fact that Croatia is a member of the EU, it is not surprising that Croatia's life insurance market is at a much higher level of development than in the other observed countries. E.g. the amount of premium collected in Albania is almost 55 times lower than in Croatia. Total premiums are rising in all countries in the region except Albania and it can even be noticed that the increase is significant. Phutkaradze (2014) points out that in post-transition countries, a strong positive link between economic growth and the development of the insurance market may not necessarily exist. This may be the reason why in some countries in the region the development of insurance has fallen behind despite some degree of economic development (e.g. Macedonia, Albania).

The data in the following table shows that the density of insurance in all Western Balkan countries is also much lower than in Croatia. The insurance density in Montenegro, Serbia, Macedonia and Albania did not differ significantly at the beginning of the observed period and was very low (below $7 €$ ). During the observed period, there was a continuous increase, except in Albania. The largest increase in this parameter was recorded in Serbia and the

Table 1. Total life insurance premium in Western Balkan countries (in €)

\begin{tabular}{cccccc}
\hline Year & Montenegro & Serbia & Croatia & Macedonia & Albania \\
\hline $\mathbf{2 0 0 6}$ & 1830082 & 51209203 & 295530827 & 1892555 & 10080404 \\
$\mathbf{2 0 0 7}$ & 5907138 & 62339032 & 338397871 & 2798668 & 14905142 \\
$\mathbf{2 0 0 8}$ & 7245771 & 71636155 & 352335260 & 4359811 & 20205128 \\
$\mathbf{2 0 0 9}$ & 8086671 & 82190996 & 338957535 & 4899076 & 5529599 \\
$\mathbf{2 0 1 0}$ & 8366637 & 88652821 & 337194108 & 5796680 & 6181643 \\
$\mathbf{2 0 1 1}$ & 9056855 & 95495251 & 326762419 & 8080103 & 7605510 \\
$\mathbf{2 0 1 2}$ & 9474402 & 104252350 & 327333482 & 9724965 & 6333275 \\
$\mathbf{2 0 1 3}$ & 10876106 & 122690181 & 33507648 & 11860158 & 6860915 \\
$\mathbf{2 0 1 4}$ & 12555901 & 132713919 & 345549704 & 14416549 & 7354467 \\
$\mathbf{2 0 1 5}$ & 12925284 & 159211666 & 385289477 & 17846577 & 7367343 \\
$\mathbf{2 0 1 6}$ & 13695992 & 187310911 & 387568965 & 20971869 & 7134645 \\
\hline
\end{tabular}


smallest in Macedonia. According to the report published by Swiss Re Institute in Sigma issue no. 3 in 2018, the average life insurance density worldwide is around $300 \$$ (260€). If we compare this data to the data of the observed countries, it is clear that all countries lag significantly behind the world life insurance market and the same is true even for Croatia, which is the most developed country in the region. Authors Osmani and Imeri (2018) find out results that confirm the views expressed so far on the poor development of the life insurance and financial markets in the observed countries. The results of their research show that Macedonia was lagging behind other countries, primarily because of foreign investors' mistrust due to the presence of high political and economic risks.

The position of insurance companies in the financial market is primarily determined by the volume of financial investments. As life insurance contracts are generally longterm, life insurers invest most of their free funds in long-term assets.

Studying Figure 1 it can be noticed that short-term financial investments of insurers from Montenegro were higher than longterm ones during the period 2006-2010, while in the period 2011-2016 long-term investments dominated. It also shows that investment in long-term assets has steadily

Table 2. Insurance density in Western Balkans

\begin{tabular}{cccccc}
\hline Year & Montenegro & Serbia & Croatia & Macedonia & Albania \\
\hline $\mathbf{2 0 0 6}$ & 2.95 & 6.91 & 66.56 & 0.92 & 3.37 \\
$\mathbf{2 0 0 7}$ & 9.53 & 8.45 & 76.28 & 1.35 & 5.02 \\
$\mathbf{2 0 0 8}$ & 11.68 & 9.75 & 79.45 & 2.11 & 6.86 \\
$\mathbf{2 0 0 9}$ & 12.87 & 11.23 & 76.53 & 2.37 & 1.89 \\
$\mathbf{2 0 1 0}$ & 13.38 & 12.16 & 76.15 & 2.80 & 2.12 \\
$\mathbf{2 0 1 1}$ & 14.48 & 13.20 & 74.19 & 3.90 & 2.62 \\
$\mathbf{2 0 1 2}$ & 15.28 & 14.48 & 76.70 & 4.69 & 2.18 \\
$\mathbf{2 0 1 3}$ & 17.54 & 17.13 & 78.73 & 5.71 & 2.37 \\
$\mathbf{2 0 1 4}$ & 20.19 & 18.61 & 81.53 & 6.94 & 2.55 \\
$\mathbf{2 0 1 5}$ & 20.77 & 22.44 & 91.66 & 8.58 & 2.56 \\
$\mathbf{2 0 1 6}$ & 22.00 & 26.54 & 92.85 & 10.08 & 2.48 \\
\hline
\end{tabular}

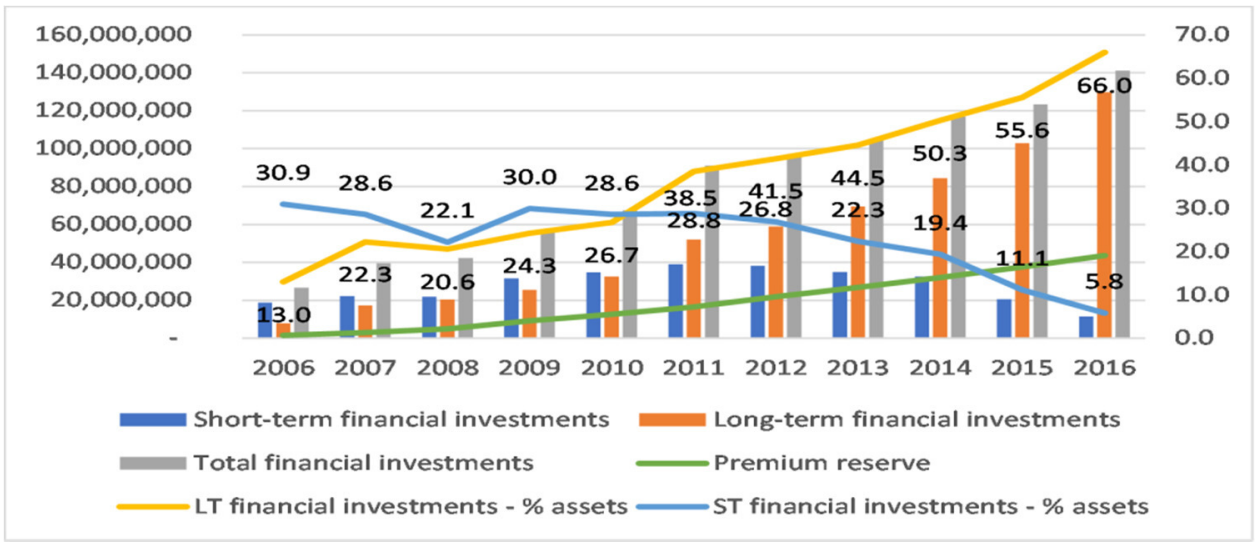

Figure 1. The structure of financial investments of insurers from Montenegro (in $€$ ) 


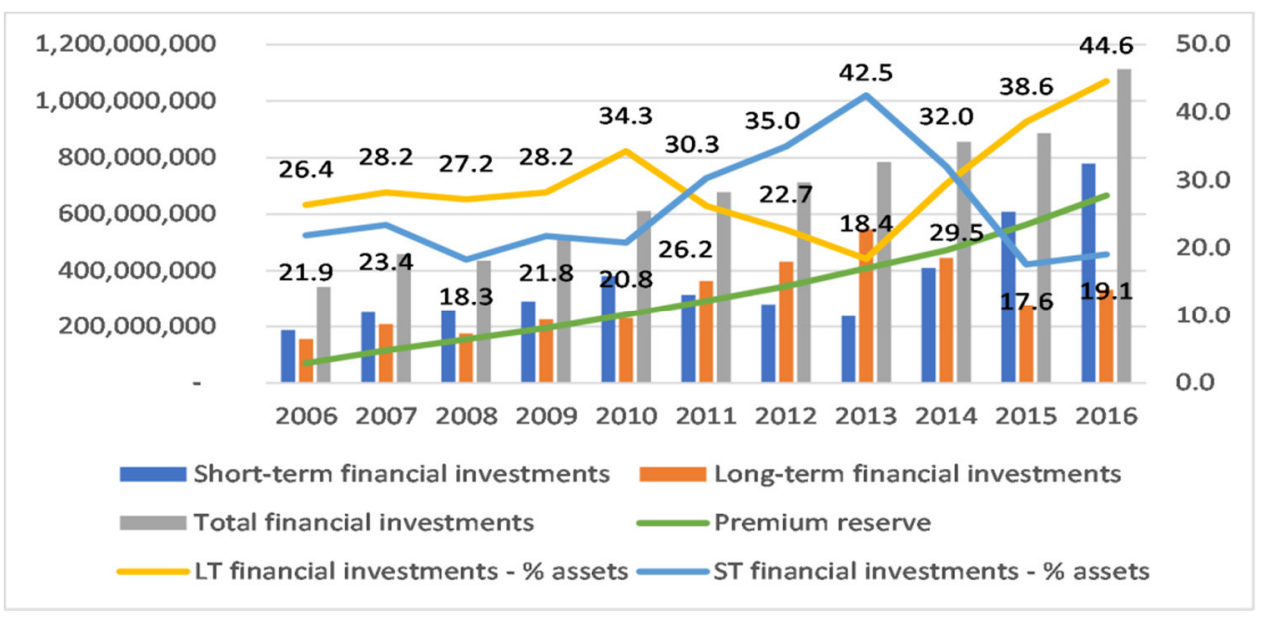

Figure 2. The structure of financial investments of insurers from Serbia (in $€$ )

increased over the period 2006-2016, while investment in short-term assets has been declining, which indicates the growth of the life insurance market, especially over the period 2013-2016. Presented data indicate that the life insurance market in Montenegro is in an upward phase of development.

In Serbia, the short-term investments are higher than long-term ones in almost every year of the observed period. Such a trend does not favor the growth and development of the life insurance market and efforts have to be made to change the relationship between long-term and short-term investments. Kočović et al. (2015) pointed out that the problem was that the financial market in Serbia was underdeveloped both in depth and breadth, characterized by a low supply of financial instruments and a low level of investment activities. Due to this general situation, insurers invested most of their funds in safer financial instruments such as short-term bonds.

The situation in Albania is very unfavorable as can be seen from Figure 3. Namely, since 2009, there has been a significant decrease in long-term and short- term investments, as well as in the total assets of insurers. It is evident that the life insurance market in Albania has failed to cope with the aftermath of the major global crisis. It is worrying that short-term investments account for almost $50 \%$ of total assets, while long-term account for only about $15 \%$ of total assets in the entire period after the major crisis. Based on these data, it can be concluded that the life insurance market in Albania is very underdeveloped and that the position of the insurance companies in the financial market is poor and unsatisfactory.

An analysis of the investments of insurers from Macedonia indicates that their position is the most unfavorable of all insurers dealing in the observed countries (Figure 4). Long-term financial investments account for only about $1 \%$ of total assets, which is absolutely not a trend that indicates the development of life insurance. Even more alarming is the fact that the share of longterm investments was decreasing year by year. Most of the total assets are short-term financial investments (even over 60\%), which undoubtedly indicates the 


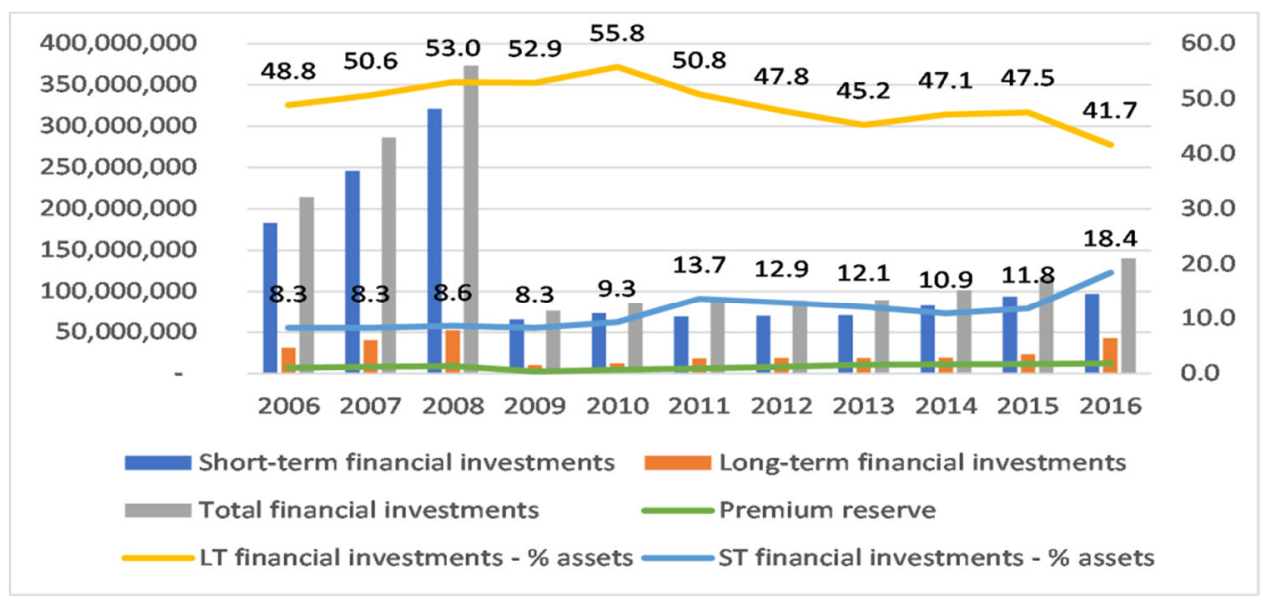

Figure 3. The structure of financial investments of insurers from Albania (in $€$ )

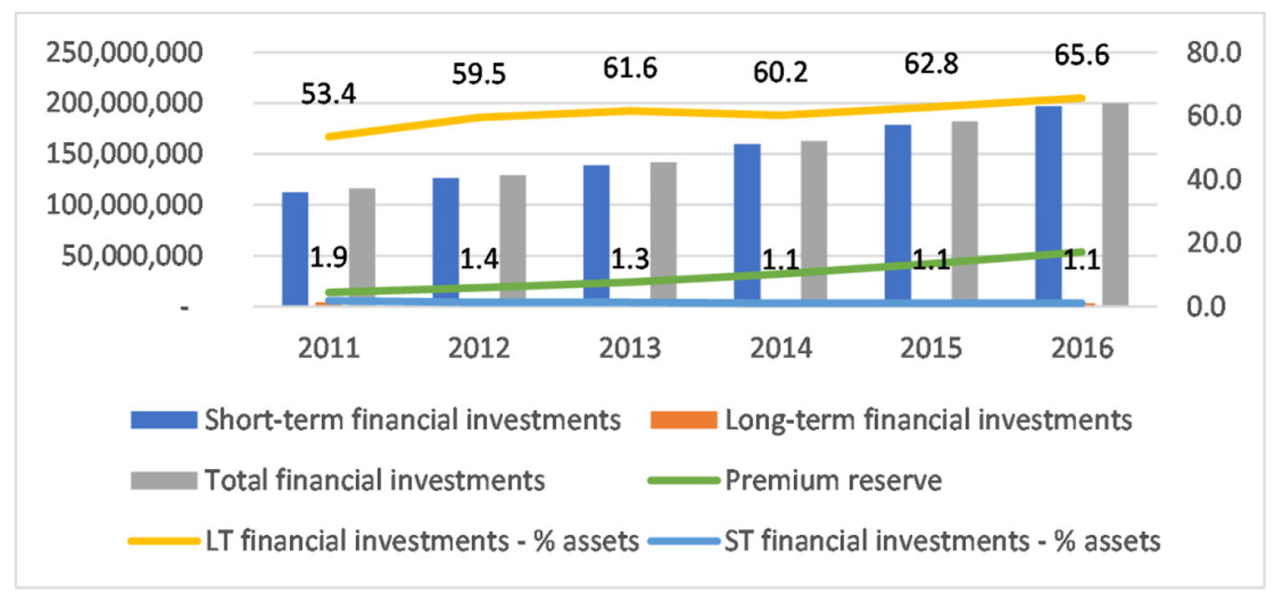

Figure 4. The structure of financial investments of insurers from Macedonia (in $€$ )

underdevelopment of the life insurance sector and the dominance of the investments in short-term assets.

As the information on short-term and long-term financial investments is not available for Croatian insurers individually, Figure 5 shows the total financial investments of insurers from Croatia.

In line with the above, it is not surprising that Croatia has the highest volume of financial investments during the observed period. Such high investments indicate that Croatian insurers have the most favorable position in the financial market of the region. Montenegro also has a favorable investment portfolio structure, characterized by a trend of long-term investment growth, which is not the case in Serbia, Macedonia and Albania.

The presented data indicate the dominance of short-term investments over long-term in all observed countries, although a trend of strengthening the proportion of long-term plasmas has been observed. The financial markets in the Western Balkans are, despite the pace of their development, still illiquid, isolated from other markets and 


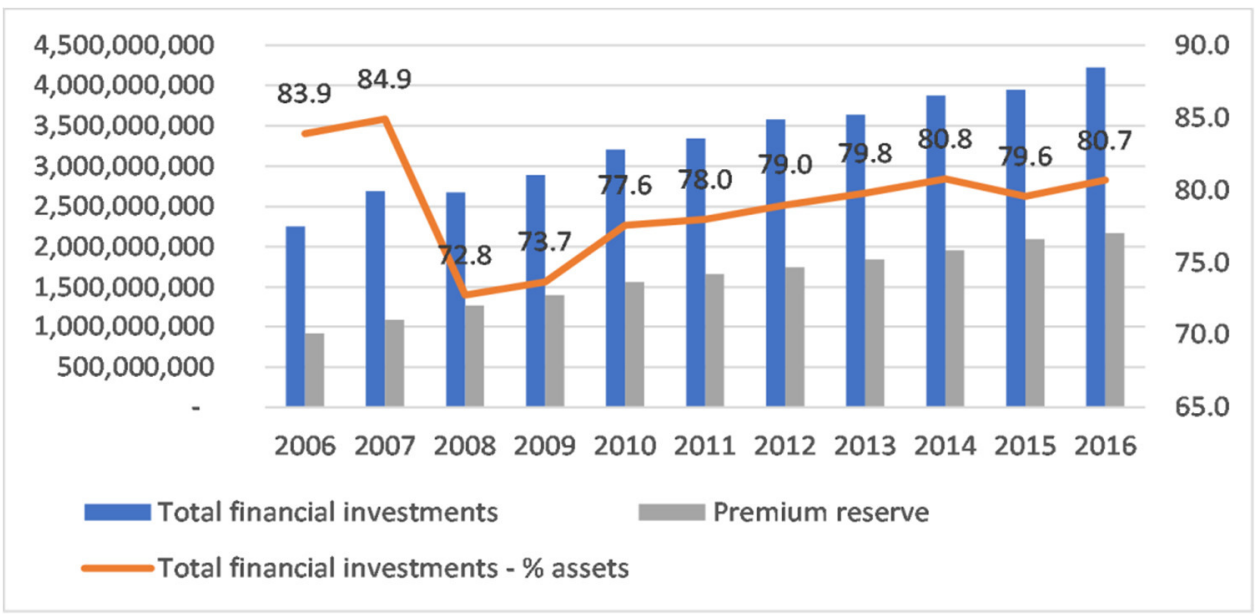

Figure 5. Financial investments of insurers from Croatia (in $€$ )

Table 3. Descriptive statistics

\begin{tabular}{ccccccc}
\hline & & Montenegro & Serbia & Croatia & Macedonia & Albania \\
\hline \multirow{2}{*}{$\begin{array}{c}\text { Premium } \\
\text { reserve }\end{array}$} & Mean & 19062783 & 320725806 & 1610396266 & 30836718 & 8378478 \\
& Standard & 16554850 & 293067204 & 1662538080 & 28169509 & 8453450 \\
& Deviation & 14467494 & 191024826 & 407897965 & 15149814 & 3012892 \\
\multirow{2}{*}{$\begin{array}{c}\text { Financial } \\
\text { placements }\end{array}$} & Mean & 82455447 & 363829696 & 3301944357 & 155462207 & 150976059 \\
& Median & 91041119 & 291737930 & 3344918438 & 152433408 & 101649260 \\
& Standard & 38100361 & 178802824 & 619244122 & 32049524 & 98538304 \\
\hline
\end{tabular}

characterized by a low transaction volume and limited mobility of capital due to high costs (Nuhiu \& Hoti, 2011). This is the basis for explaining why the structure of financial investments in the observed countries is more oriented towards short-term and safer investments. All papers dealing with the financial market in Western Balkan countries point out that financial markets are in the development phase, with the need for their further improvement. These markets are dominated by banks as financial institutions and government bonds as financial instruments. (Stojaković \& Jeremić, 2016; Nuhiu \& Hoti, 2011; Cerović et al., 2013). The median and average values of premium reserves and financial investments of the observed countries of the region in the period 2006-2016, as well as their deviation from the average, i.e. standard deviation, are shown in Table 3.

Table 3 shows that the premium reserve in Serbia and Montenegro reached significant values in some years, which affected its mean, while in other countries, it was approximately uniformly distributed, as shown by previous figures in the paper. Similar is with financial investments, except in Albania where financial investments have reached extreme values in some years, which led to a significant deviation of the value of median from the mean. 


\section{METHODOLOGY OF RESEARCH where:}

This paper starts from the assumption that life insurance has a positive impact on the development of the financial market, and thus on the development of the overall economic system of Western Balkan countries.

The most important parameters of the life insurance market development are: the total life insurance premium, the share of life insurance premium in the total insurance premium for all types of insurance, density and penetration of life insurance, number of life insurance companies, etc.

Correlation and regression methods were used to examine the impact of the premium reserve on the volume of financial investments of life insurance companies in Western Balkan countries. The correlation and regression analysis presented in this paper were obtained using IBM SPSS Statistics Software.

A premium reserve is taken for the independent variable, and financial investments represent the dependent variable. The regression model is:

$$
\mathrm{Y}_{i}=\alpha+\beta \mathrm{X} i+\varepsilon
$$

$\mathrm{X}$ - the independent variable (predictor),

$\mathrm{Y}$ - the dependent variable (response),

$\alpha$-intercept (shows what the value of the response would be if the value of the predictor is 0 ),

$\beta-$ a regression coefficient that shows how much the average of a dependent variable changes if the independent variable increases by one unit,

$\varepsilon$ - the error term that measures the amount of variation in Y not explained by the model.

First, an analysis was made on premium reserve and financial investment data for all countries in the region. However, many of the necessary assumptions (Poole \& O'Farrell, 1971), were violated, leading to incorrect results and correlation and regression analysis had to be done on a country-by-country basis.

\section{RESULTS AND DISCUSSION}

The correlation analysis conducted for Montenegro is shown in Table 4.

Table 4. Correlation coefficients between observed variables - Montenegro

Correlations

\begin{tabular}{llrr}
\hline & & Premium_Reserve & $\begin{array}{c}\text { Financial_ } \\
\text { Investments }\end{array}$ \\
\hline \multirow{2}{*}{ Premium Reserve } & Pearson & 1 & $.983^{* *}$ \\
& Correlation & & .000 \\
& Sig. (2-tailed) & 11 & 11 \\
& $\mathrm{~N}$ & $.983^{* *}$ & 1 \\
Financial & Pearson & .000 & \\
Investments & Correlation & 11 & 11 \\
& Sig. (2-tailed) & & \\
& $\mathrm{N}$ & &
\end{tabular}

**. Correlation is significant at the 0.01 level (2-tailed). 
Table 5. Regression coefficients - Montenegro

Coefficients $^{\text {a }}$

\begin{tabular}{|c|c|c|c|c|c|c|}
\hline \multicolumn{2}{|r|}{ Model } & \multicolumn{2}{|c|}{ Unstandardized Coefficients } & \multicolumn{3}{|c|}{ Standardized Coefficients } \\
\hline & & B & Std. Error & Beta & $\mathrm{t}$ & Sig. \\
\hline \multirow{2}{*}{1} & (Constant) & 33089977.625 & (3755 348.177) & & 8.811 & .000 \\
\hline & Premium_Reserve & 2.590 & $(.160)$ & .983 & 16.226 & .000 \\
\hline 2 & $\begin{array}{l}\text { Adjusted R-squared: } \\
\text { F-statistic: }\end{array}$ & \multicolumn{5}{|c|}{0.9633} \\
\hline 3 & $\begin{array}{l}\text { Studentized Breusch- } \\
\text { Pagan test } \\
\text { Null: } \\
\text { Homoscedasticity }\end{array}$ & \multicolumn{5}{|c|}{$\mathrm{BP}=0.1041 . \mathrm{df}=1 . \mathrm{p}$-value $=0.7469$} \\
\hline 4 & $\begin{array}{l}\text { Breusch-Godfrey test } \\
\text { Null: No serial } \\
\text { correlation in errors }\end{array}$ & \multicolumn{5}{|c|}{ LM test $=2.0293 . \mathrm{df}=1 . \mathrm{p}$-value $=0.1543$} \\
\hline
\end{tabular}

a. Dependent Variable: Financial_Investments

The correlation coefficient between the premium reserve and financial investments for Montenegro is 0.983 , which indicates a strong positive correlation among these variables. In order to determine the form of relationship between them, a regression analysis must be performed. The results of the regression model at the level of Montenegro are shown in Table 5.

The coefficient of determination is 0.9633 and the $\mathrm{F}$ test confirms the validity of the model with an accuracy greater than $99 \%$ (pvalue $=5.692 \mathrm{e}-08)$. The tests for homoscedasticity and non-correlation of the regressors confirm the null hypothesis, which means that the regression model is valid.

The following regression equation is derived:

Financial Investments $=33,089,977.625$ $+2.59 *$ Premium Reserve

Based on that relation, it follows that the volume of financial investments will increase 2.59 times if the amount of premium reserve is increased by one unit. Thus, the growth of life insurance premiums and thereby premium reserves as the key component of technical reserves more than double increase the amount of financial investments. The value of $33,089,977.625 €$ shows that the value of financial investments when the value of the premium reserve is $0 €$.

The same variables are observed for Serbia and the obtained results are shown in Table 6 and Table 7.

Based on the results shown in Table 6, it can be observed that the correlation coefficient among the observed variables for Serbia is 0.988 , i.e. there is a strong positive correlation between premium reserve and financial investments. In accordance with the results obtained using the regression analysis, it can be noticed that the growth of the premium reserve of insurers in Serbia by one unit increases the volume of financial investments by 1.18 times. If the premium reserve equals 0 , then the volume of financial investments in Serbia is 292,550,563.949€.

Comparing the results of the regression analysis for Montenegro and Serbia, it can be concluded that the change in the volume of premium reserve has two times greater 
Table 6. Correlation coefficients between observed variables - Serbia

\section{Correlations}

\begin{tabular}{llrr}
\hline & & Premium_Reserve & $\begin{array}{c}\text { Financial_ } \\
\text { Investments }\end{array}$ \\
\hline \multirow{2}{*}{ Premium Reserve } & Pearson Correlation & 1 & $.988^{* *}$ \\
& Sig. (2-tailed) & & .000 \\
& $\mathrm{~N}$ & 11 & 11 \\
& Pearson Correlation & $.988^{* *}$ & 1 \\
Financial Investments & Sig. (2-tailed) & .000 & \\
& $\mathrm{~N}$ & 11 & 11 \\
\hline **. Correlation is significant at the 0.01 level (2-tailed). & &
\end{tabular}

Table 7. Regression coefficients - Serbia

Coefficients $^{\text {a }}$

\begin{tabular}{|c|c|c|c|c|c|c|}
\hline \multicolumn{2}{|r|}{ Model } & \multicolumn{2}{|c|}{ Unstandardized Coefficients } & \multicolumn{3}{|c|}{ Standardized Coefficients } \\
\hline & & B & Std. Error & Beta & $\mathrm{t}$ & Sig. \\
\hline & (Constant) & 292550563.949 & $(22899787.325)$ & & 12.775 & .000 \\
\hline 1 & Premium_Reserve & 1.185 & $(.062)$ & .988 & 19.086 & .000 \\
\hline 2 & $\begin{array}{c}\text { Adjusted R-squared: } \\
\text { F-statistic: } \\
\text { Studentized }\end{array}$ & 364.3 & $\begin{array}{c}0.9732 \\
\text { on } 1 \text { and 9 DF.p-vic }\end{array}$ & lue: 1. & 71e-08 & \\
\hline 3 & $\begin{array}{l}\text { Breusch-Pagan test } \\
\text { Null: } \\
\text { Homoscedasticity }\end{array}$ & $\mathrm{BP}=$ & 0.7921. df $=1 . \mathrm{p}-\mathrm{v}$ & alue $=$ & .3735 & \\
\hline 3 & $\begin{array}{c}\text { Breusch-Godfrey } \\
\text { test } \\
\text { Null: No serial } \\
\text { correlation in errors }\end{array}$ & LM test & $=0.6165 . \mathrm{df}=1.1$ & -value & $=0.4324$ & \\
\hline
\end{tabular}

a. Dependent Variable: Financial_Investments

impact on the volume of financial response to changes in another variable, investments in Montenegro than in Serbia. when the market is less developed. There are The reason is that the life insurance sector no bond offers in the financial market of and the financial market are at a higher level Montenegro, primarily state and corporate of development in Serbia than in ones, and there is a dominance of investing Montenegro, and therefore a small change in insurers' funds in bank deposits, which the volume of premium reserve leads to a indicates that the Montenegrin market is less much larger change in the volume of developed, not only in comparison to the financial investments in Montenegro than in Croatian, but also with the Serbian financial Serbia. Due to the greater growth potential and life insurance markets (Žarković, 2011). and development, changes in one variable Considering the offer of financial are much higher and more significant in instruments in the Montenegrin financial 
Table 8. Correlation coefficients between observed variables - Croatia

\section{Correlations}

\begin{tabular}{llrr}
\hline & & Premium_Reserve & $\begin{array}{c}\text { Financial_ } \\
\text { Investments }\end{array}$ \\
\hline \multirow{2}{*}{ Premium Reserve } & Pearson Correlation & 1 & $.990^{* * *}$ \\
& Sig. (2-tailed) & & .000 \\
& $\mathrm{~N}$ & 11 & 11 \\
& Pearson Correlation & $.990^{* *}$ & 1 \\
Financial Investments & Sig. (2-tailed) & .000 & \\
& $\mathrm{~N}$ & 11 & 11 \\
\hline **. Correlation is significant at the 0.01 level (2-tailed). & &
\end{tabular}

Table 9. Regression coefficients - Croatia

Coefficients $^{\text {a }}$

\begin{tabular}{|c|c|c|c|c|c|c|}
\hline \multicolumn{2}{|r|}{ Model } & \multicolumn{2}{|c|}{ Unstandardized Coefficients } & \multicolumn{3}{|c|}{ Standardized Coefficients } \\
\hline & & B & Std. Error & Beta & $\mathrm{t}$ & Sig. \\
\hline 1 & (Constant) & 882403740.129 & $(120198841.584)$ & & 7.341 & .000 \\
\hline 1 & Premium_Reserve & 1.502 & $(.073)$ & .990 & 20.708 & .000 \\
\hline 2 & $\begin{array}{l}\text { Adjusted R- } \\
\text { squared: } \\
\text { F-statistic: }\end{array}$ & 428 & $\begin{array}{r}0.9772 \\
8 \text { on } 1 \text { and } 9 \text { DF. p-v }\end{array}$ & alue: 6 & $679 e-09$ & \\
\hline 3 & $\begin{array}{c}\text { Studentized } \\
\text { Breusch-Pagan test } \\
\text { Null: } \\
\text { Homoscedasticity }\end{array}$ & & $=1.7012 . \mathrm{df}=1 . \mathrm{p}-\mathrm{I}$ & alue $=$ & 0.1921 & \\
\hline 2 & $\begin{array}{c}\text { Breusch-Godfrey } \\
\text { test } \\
\text { Null: No serial } \\
\text { correlation in errors }\end{array}$ & $\mathrm{LM}$ & est $=0.8518 . \mathrm{df}=1$. & p-valu & $=0.356$ & \\
\hline
\end{tabular}

a. Dependent Variable: Financial_Investments

market, and the low returns on insurer investments due to the dominance of bonds and investments in banks, as a form of financial assets, it is clear that a higher volume of financial placements is required to cover the long-term liabilities of the insurer, i.e. the premium reserve, and to provide liquidity and solvency. More precisely, there is considerable sensitivity between the premium, and therefore the insurance reserves, and the interest rate in the financial market, that is, a lower interest rate increases the demand for life insurance, compared to the demand for other forms of savings, which increases the investments of insurers (Lenten \& Rulli, 2006; Fortune, 1973).

Given that the life insurance sector has proved to be the most developed in Croatia so far, it is interesting to see the results of correlation and regression analysis for Croatia (Tables 8 and 9).

The results of correlation analysis show 
that the highest correlation coefficient between premium reserve and financial investments is in Croatia at 0.99. This result is on the same level as the expectations. The correlation coefficient in Serbia (0.988) is almost at the same level as the one measured in Croatia, while the mentioned coefficient in Montenegro is lower by about 0.07 .

It can be seen (Table 8 ) that by increasing the volume of premium reserve by one unit the volume of financial investments increases 1.5 times. If we compare the results of the regression analysis for Montenegro, Serbia and Croatia, it can be concluded that the regression coefficient in Croatia is smaller than in Montenegro (2.59) but at the same time higher than in Serbia (1.18). At first glance, this result is surprising but also logical considering certain market mechanisms and how they work. The causeand-effect relationship among the variables are very strong when the economy is in the phase of growth and development while decreasing when a certain, higher level of development is reached. As the life insurance market in Montenegro is in the early stages of growth, so the potential of growth exists, the links between the premium reserve and financial investments, i.e. between the insurance market and the financial market, are more expressed. On the other hand, the Croatian insurance market is at a much higher level of development, so changes in variables resulting from changes in other variables are less stressed. Accordingly, it would be expected that the regression coefficient for Serbia is higher than for Croatia. The opposite result can be explained by restrictive rules for investing free funds in Serbia, which were tightened in 2014. This situation is contrary to current trends in the investment activity of insurers in the European Union. Also, inadequate availability of financial instruments, prices and yield movements, negatively affect the role of Serbian insurers as institutional investors (Kočović et al., 2015).

The results of the correlation and regression analysis for Macedonia are given in Tables 10 and 11.

Correlation analysis shows that the correlation coefficient among the observed variables in Macedonia is 0.930 , which means that there is a strong positive correlation between premium reserve and financial investments in this country.

Table 10. Correlation coefficients between observed variables - Macedonia

Correlations

\begin{tabular}{llrr}
\hline & & Premium_Reserve & $\begin{array}{c}\text { Financial_ } \\
\text { Investments }\end{array}$ \\
\hline & Pearson & 1 & $.930^{* *}$ \\
Premium Reserve & Correlation & & .000 \\
& Sig. (2-tailed) & 11 & 11 \\
& $\mathrm{~N}$ & $.930^{* *}$ & 1 \\
Financial & Pearson & .000 & \\
Investments & Correlation & 11 & 11 \\
& Sig. (2-tailed) & & \\
\hline$* *$ Correlation is significant at the 0.01 level (2-tailed). & &
\end{tabular}


However, it is evident that this coefficient is slightly lower than in other countries in the region (except Albania). This result is expected given the fact that both, the life insurance market and the financial market in Macedonia, are less developed than in Montenegro, Serbia and Croatia. Based on the regression equation (Table 10), it can be noticed that the increase of the premium reserve in Macedonia for one unit leads to a 7.8-fold increase in financial investments. Changing the volume of premium reserve has the biggest impact on changing the volume of financial investments in Macedonia. Given that the life insurance market in Macedonia is highly underdeveloped, any change in variables is intensely reflected in changes in other variables, and therefore the obtained results are justified. More specifically, Macedonia's life insurance market, excluding Albania, has the lowest level of development compared to all other Western Balkan countries. This result is conditioned by the specificities of the market such as, for example, underdeveloped insurance culture, both for citizens and businesses, poor supply of financial instruments, but also disinterest of European insurers to invest in Macedonia due to the presence of political, security and economic risks stemming from the fact that Macedonia is seriously stagnant in the EU integration process (Osmani \& Imeri, 2018).

Correlation and regression analysis was performed for Albania too. The correlations between the variables are shown in Table 12.

Table 12 shows that the correlation coefficient is the lowest in Albania and is only 0.783 . This result is in line with the level of development of the overall economy.

Further analysis determined the invalidity of the regression model for Albania (Fstatistic: 0.2044 on 1 and 9 DF, p-value: 0.6619). The autocorrelation of residuals for this country was also identified because the Breusch-Godfrey test rejected the null hypothesis with a probability greater than $96 \% \quad(\mathrm{LM} \quad$ test $=4.4626, \quad \mathrm{df}=1, \quad \mathrm{p}$ value $=0.03464)$. After the HAC robust standard error estimation, the coefficients for the premium reserve and the constant term remained statistically insignificant. This

Table 11. Regression coefficients - Macedonia

Coefficients $^{\text {a }}$

\begin{tabular}{|c|c|c|c|c|c|c|}
\hline \multicolumn{2}{|r|}{ Model } & \multicolumn{2}{|c|}{ Unstandardized Coefficients } & \multicolumn{3}{|c|}{ Standardized Coefficients } \\
\hline & & $\mathrm{B}$ & Std. Error & Beta & $\mathrm{t}$ & Sig. \\
\hline 1 & (Constant) & 36420000 & (10 450000$)$ & & 3.486 & .007 \\
\hline 1 & Premium_Reserve & 3.5 & $(.4123)$ & 0.990 & 8.489 & .001 \\
\hline 2 & $\begin{array}{l}\text { Adjusted R-squared: } \\
\text { F-statistic: }\end{array}$ & \multicolumn{5}{|c|}{$\begin{array}{c}0.9772 \\
428.8 \text { on } 1 \text { and } 9 \text { DF.p-value: } 6.679 \mathrm{e}-09\end{array}$} \\
\hline 3 & $\begin{array}{c}\text { Studentized } \\
\text { Breusch-Pagan test } \\
\text { Null: } \\
\text { Homoscedasticity }\end{array}$ & \multicolumn{5}{|c|}{$\mathrm{BP}=1.7012 . \mathrm{df}=1 . \mathrm{p}$-value $=0.1921$} \\
\hline 4 & $\begin{array}{c}\text { Breusch-Godfrey } \\
\text { test } \\
\text { Null: No serial } \\
\text { correlation in errors }\end{array}$ & \multicolumn{5}{|c|}{ LM test $=0.8518 . \mathrm{df}=1 . \mathrm{p}$-value $=0.356$} \\
\hline
\end{tabular}

a. Dependent Variable: Financial_Investments 
Table 12. Correlation coefficients between observed variables - Albania

\section{Correlations}

\begin{tabular}{|c|c|c|c|}
\hline & & Premium_Reserve & $\begin{array}{l}\text { Financial_ } \\
\text { Investments }\end{array}$ \\
\hline \multirow{3}{*}{ Premium Reserve } & $\begin{array}{l}\text { Pearson } \\
\text { Correlation }\end{array}$ & 1 & $.783^{*}$ \\
\hline & Sig. (2-tailed) & & .022 \\
\hline & $\mathrm{N}$ & 8 & 8 \\
\hline \multirow{3}{*}{$\begin{array}{l}\text { Financial } \\
\text { Investments }\end{array}$} & $\begin{array}{l}\text { Pearson } \\
\text { Correlation }\end{array}$ & $.783^{*}$ & 1 \\
\hline & Sig. (2-tailed) & .022 & \\
\hline & $\mathrm{N}$ & 8 & 8 \\
\hline
\end{tabular}

*. Correlation is significant at the 0.05 level (2-tailed).

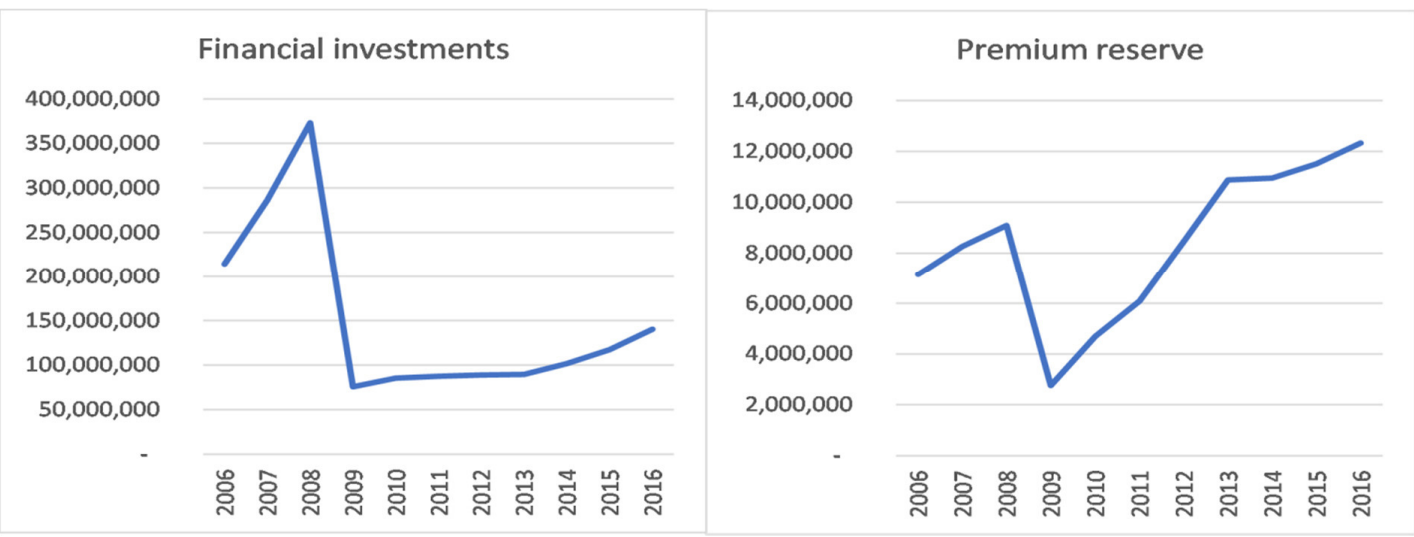

Figure 6. Movement of premium reserve and investments in Albania (in $€$ )

indicates that the volume of investments does not depend on the volume of premium reserve in Albania. Figure 6 shows that the premium reserve and financial investments initially have a similar trend, but after the beginning of the crisis 2008 , the premium reserve continues to grow, while investments stagnating until 2015. More specifically, the foreign investments in Albania have had a positive impact on both the life insurance trend and the improvement of the overall financial market. However, other economic, political and social factors have negatively affected the further pace of market development, as well as on investment decisions of both citizens and institutional investors, especially when the consequences of the financial crisis began to be felt (Sherifi, 2015). As Albania's financial market was not fully integrated into the global financial market it was growing at the beginning of the crisis. There were no complex financial instruments through which the effects of the financial crisis could be manifested. However, after 2009, the crisis consequences suddenly started to feel, which might be one of the reasons for the stagnation of total investments in the financial market (Sherifi \& Turan, 2018). Namely, the insurers' distrust in the financial 
market functioning, after the problems caused by the crisis, maybe one of the reasons of decreasing investments of insurers in financial instruments in Albania.

\section{CONCLUSION}

The underdeveloped financial market directly affects the underperformance of life insurance companies. Namely, if the financial market is underdeveloped, then there are a small number of instruments in which insurers can invest their funds, and thus there is also less incentive to invest, less yield and financial market impact on insurance development. The underdeveloped financial market is a problem in all countries in the Western Balkans, and it is necessary to make efforts on its further improvement in order to stimulate the growth of the life insurance sector. On the other hand, through the role of institutional investors, life insurance companies promote the development of the financial market.

Analyzing the volume and structure of financial investments of insurers in the countries of Western Balkan, it can be concluded that insurers operating in the markets of Montenegro and Albania, show a steady increase in investments in long-term assets, indicating that their role as institutional investors is becoming increasingly important. In the observed period, long-term financial investments in Macedonia decreased, while short-term investments in Serbia were higher than longterm ones in almost every observed year. Also, by comparing long-term financial investments of all countries, except Croatia, it can be concluded that insurers in Montenegro have a more favorable position in the financial market than insurers in other countries in the region.

The results obtained after the regression analysis showed that there was a positive correlation between the volume of premium reserve and the volume of financial investments in all observed countries. More specifically, in all countries of the region, an increase in the volume of premium reserve causes an increase in the volume of financial investments. Correlation is strong and positive (above 0.90) in all countries, except Albania.

The regression analysis for Western Balkan countries indicates that there is a strong influence of the changes of premium reserve on the changes of the amount of financial investments in the observed countries, except in Albania. The increase of premium reserve for one unit leads to the increase of financial investments by 3.5 times in Macedonia; 2.59 times in Montenegro; 1.5 times in Croatia and 1.18 times in Serbia. Although the Croatian insurance market is at a much higher level of development than the Serbian, the regression coefficient is the lowest in Serbia. As earlier mentioned, the restrictive policy of investing insurers' free funds in the financial market, as well as the trend of the dominance of short-term financial assets in the investment portfolio of life insurance companies in Serbia, over the observed period, indicates a low potential of life insurance market development in relation to all other observed countries. This justifies the regression coefficient which is the lowest in Serbia.

The results of this research should be a clear signal to the regulators of the insurance market in observed Western Balkan countries, that in cooperation with other participants, both the insurance market and other segments of the financial market, contribute to the further growth and 
development of the life insurance market, as well as through regulation and rules relating to the investment of free funds of technical reserve influence the increase in the volume of long-term investments in the structure of insurance companies' investment portfolio.

Unavailability of data, e.g. at the quarterly or monthly level, which would increase the significance of the results of the regression analysis, as well as the data for some of the countries belonging to this region, was a major limitation. An important limitation of the research was the fact that it had not been possible to obtain data at the level of insurance companies in each of the observed countries, but only at the level of the insurance market. However, despite these limitations, the results may be significant for future research, which would, for example, include developed markets or other regions in comparative analysis. The obtained results should incite on research how some other factors, e.g. investment rules and other regulations, investments strategies, policies and similar, can affect the position of life insurance companies in the financial market. Also, for the countries where data by insurance companies are available, future research, instead of at the aggregate level, could be done at the individual level which would certainly increase the significance of the research.

\section{References}

Apergis, N., \& Poufinas, T. (2020). The role of insurance growth in economic growth: Fresh evidence from a panel of OECD countries. The North American Journal of Economics and Finance, 53(C). 101217

Arena, M. (2008). Does Insurance Market
Activity Promote Economic Growth? A Cross-Country Study for Industrialized and Developing Countries. Journal of Risk, 75 (4), 921-946.

Bejtja, M. (2018). Albanian Insurance Market Analyses and their Business Model. Academic Journal of Interdisciplinary Studies, 7 (3), 157-177.

Cerović, J., Drobnjak, R., \& Lajović, D. (2013). Financial Market of Montenegro: Evidence of Crisis and Beyond. Journal of Modern Accounting and Auditing, 9 (9), 1246-1252.

Dervishi, B. (2020). Investments and portfolio structure of private pension and insurance companies in North Macedonia. International Journal Of Research In Business And Social Science 9 (5), 227-234.

Fortune, P. (1973). A Theory of Optimal Life Insurance: Development and Tests. Journal of Finance, 28 (3), 587-600.

Kašćelan, V., \& Radulović, B. (2008). Insurance companies in the financial market in the region. Montenegrin Journal of Economics, 4 (7), 5-15 (in Serbian).

Kočović, J., Paunović, B., \& Jovović, M. (2015). Possibilities of creating optimal investment portfolio of insurance companies in Serbia. Ekonomika preduzeća, 63 (7-8), 385-398.

Kjosevski, J. (2012). The determinants of life insurance demand in central and southeastern Europe. International Journal of Economics and Finance, 4 (3), 237-247.

Kozarević, S., Kozarević, E., \& Šiljegović, E. (2011). Development of the insurance sector in the Western Balkan countries: the drive towards the European Union insurance system. International Journal of Economic Policy in Emerging Economies, 4 (3), 287-302.

Kukaj, H., Morina, F., \& Misiri, V. (2019). The Effects of the Insurance Market 


\title{
УТИЦАЈ ПРЕМИЈСКЕ РЕЗЕРВЕ НА УЛАГАЊА У ЖИВОТНО ОСИГУРАЫЕ НА ЗАПАДНОМ БАЛКАНУ
}

\author{
Јелена Томашевић, Милијана Нововић Бурић, Љиљана Кашћелан, \\ Владимир Кашћелан
}

\section{Извод}

Све већи значај животног осигурања у свету намеће све већу потребу за истраживањем у овој области, посебно на Западном Балкану где је тренд раста уско праћен животним осигурањем у последње две деценије. Узимајући у обзир да су компаније за животно осигурање значајни учесници на финансијском тржишту, овај истраживачки рад испитује утицај премијске резерве на обим финансијских улагања друштава за животно осигурање у земљама Западног Балкана, на основу збирних података на нивоу земље. У циљу тестирања његовог ефекта коришћени су модели линеарне корелације и регресије, на основу података прикупљених за период 2006-2016. Поред тога, компаративна анализа је коришћена за поређење положаја друштава за животно осигурање на финансијским тржиштима. Резултати добијени применом корелационе и регресионе анализе показали су да постоји јака позитивна корелација између премијских резерви и финансијских улагања у свим наведеним земљама региона. Овај резултат је важна стратешка смјерница за регулаторе и креаторе политике за напредак у сектору животног осигурања, као и на финансијском тржишту Западног Балкана.

Кључне речи: премијска резерва, финансијска улагања, животно осигурање, регресија, корелација

in the Development of Western Balkans Countries, with Special Emphasis on Kosovo. European Journal of Sustainable Development, 8 (2), 209.

Labudović, J. (2007). Importance and Role of Life Insurance Companies as Institutional Investors on Financial Market", European Insurance Law Review, 4 (7), 30.

Labudović, J. (2008). Life Insurance Contracts and Their Influence on Investment Policy. European Insurance Law Review, 4 (8), 40.

Lenten, J.A., \& Rulli, D.N. (2006). A Time-Series Analysis of the Demand for Life Insurance Companies in Australia: An Unobserved Components Approach. Australian Journal of Management, 31 (1), 41-66.
Müller-Jentsch, D. (2007.) Financial sector restructuring and regional integration in the Western Balkans. Washington, D.C.: World Bank Group. http://documents.worldbank.org/curated/en/ 760431468275694776/Financial-sectorrestructuring-and-regional-integration-inthe-Western-Balkans

Novović Burić, M., Cerović Smolović, J., Lipovina Božović, M., \& Lalević Filipović, A. (2017). Impact of economic factors on life insurance development in Western Balkan Countries. Zbornik radova Ekonomski fakultet Rijeka, 35 (2), 331-352.

Nuhiu, A.R., \& Hoti, A.H. (2011). Effects of capital markets development on economic growth of Western Balkan countries. European Journal of Economics, Finance 
and Administrative Sciences, 43, 88-98.

Omarkhanova, Z., Amerzhanova, D., Mardenova, L., Zayakina, A. \& Sartova, R. (2019). Statistical methods in investment insurance. Entrepreneurship and Sustainability Issues 7 (2): 1582-1598.

Osmani, R., \& Imeri, M. (2018). The development of the insurance market in the Republic of Macedonia. Ecoforum Journal, 7 (1), 468-477.

Peleckienè, V., Peleckis, K., Dudzevičiūtè, G. \& Peleckis, K.K. (2019). The relationship between insurance and economic growth: evidence from the European Union countries, Economic Research-Ekonomska Istraživanja, 32 (1), 1138-1151

Phutkaradze, J. (2014). Impact of insurance market on economic growth in post-transition countries. International Journal of Management and Economics, 44 (1), 92-105.

Piljan, I., Cogoljević, D., \& Piljan, T. (2015). Role of insurance companies in financial market. International Review, (12), 94-102.

Poole, M.A., \& O'Farrell, P.N. (1971). The assumptions of the linear regression model. Transactions of the Institute of British Geographers. London, United Kingdom: Wiley-Blackwell $\square$, 145-158.

Pradhan, R., Arvin, M., Nair, M. \& Bennett, S.(2020). Unveiling the causal relationships among banking competition, stock and insurance market development, and economic growth in Europe. Structural Change and Economic Dynamics. 55, 74-87.

Sawadogo, R., Guerineau, S., \& Ouedraogo, I.M. (2018). Life insurance development and economic growth: evidence from developing countries. Journal of Economic Development, 43 (2), 1-28.

Sherifi, Ç., \& Turan, G. (2018). Global
Financial Crises: The Impact on Albanian Economic Growth. European Journal of Economics and Business Studies, 4 (1), 279294.

Sherifi, I. (2015). Insurance sector in Albania: History and Development. European Journal of Business, Economics and Accountancy, 3 (5), 6-11.

Stojaković, A., \& Jeremić, L. (2016). Development of the insurance sector and economic growth in countries in transition. Megatrend revija, 13 (3), 83-106.

Ward, D., \& Zurbruegg, R. (2000). Does insurance promote economic growth? Evidence from OECD countries. Journal of Risk and Insurance, 67 (4), 489-506.

Webb, I.P., Grace, M.F., \& Skipper, H.D. (2002). The effect of banking and insurance on the growth of capital and output. Centre for Risk Management and Insurance. Working Paper No. 02-1. Robinson College of Business, Georgia State University, Atlanta.

Žarković, N., Lisov, M., \& Mrkšić, D. (2011). Investments Of Serbian Insurance Companies. Economic Research, 24 (1), 1113-1126.

\section{Website References}

Albanian financial supervisory authority. [online] Available at: https://amf.gov.al/ (accessed 10 November 2019).

Croatian Financial Services Supervisory Agency. [online] Available at: https://www.hanfa.hr/ (accessed 10 November 2019).

Insurance Supervision Agency Montenegro. [online] Available at: https://www.ano.me (accessed: 10 November 2019).

National Bank of Serbia. [online] 
Available at: https:/www.nbs.rs/ (accessed 10 November 2019).

The Insurance Supervision Agency of the Republic of Macedonia. [online] Available at: www.aso.mk/) (accessed 10 November 2019]. 